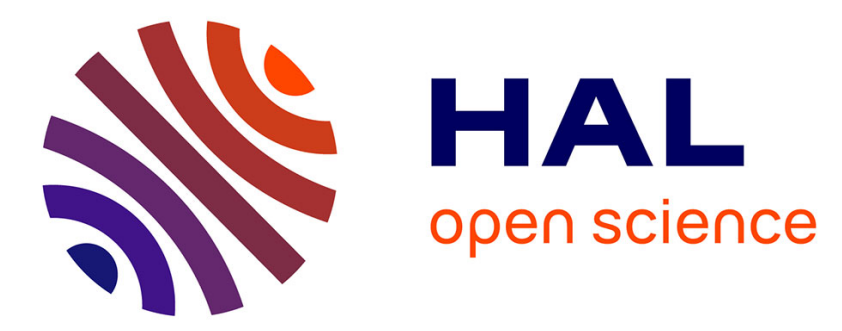

\title{
Bleaching and necrosis of staghorn coral (Acropora formosa) in laboratory assays: Immediate impact of LDPE microplastics
}

A. D. Syakti, Jeales Veva Jaya, Dede Aulia Rahman, Nuning Vita Hidayati, Tengku Said Raza'I, Fadliyah Idris, Mukti Trenggono, Pierre Doumenq

\section{To cite this version:}

A. D. Syakti, Jeales Veva Jaya, Dede Aulia Rahman, Nuning Vita Hidayati, Tengku Said Raza'I, et al.. Bleaching and necrosis of staghorn coral (Acropora formosa) in laboratory assays: Immediate impact of LDPE microplastics. Chemosphere, 2019, 228, pp.528-535. 10.1016/j.chemosphere.2019.04.156 . hal-02479051

\section{HAL Id: hal-02479051 \\ https://hal.science/hal-02479051}

Submitted on 14 Feb 2020

HAL is a multi-disciplinary open access archive for the deposit and dissemination of scientific research documents, whether they are published or not. The documents may come from teaching and research institutions in France or abroad, or from public or private research centers.
L'archive ouverte pluridisciplinaire HAL, est destinée au dépôt et à la diffusion de documents scientifiques de niveau recherche, publiés ou non, émanant des établissements d'enseignement et de recherche français ou étrangers, des laboratoires publics ou privés. 


\title{
Bleaching and necrosis of staghorn coral (Acropora formosa) in laboratory assays: Immediate impact of LDPE microplastics
}

\author{
Agung Dhamar Syakti a, b, *, Jales Veva Jaya ${ }^{\text {b }}$, Aulia Rahman ${ }^{\text {c }}$, Nuning Vita Hidayati ${ }^{\text {d }}$, \\ Tengku Said Raza'i ${ }^{\mathrm{b}}$, Fadliyah Idris ${ }^{\mathrm{b}}$, Mukti Trenggono ${ }^{\mathrm{d}}$, Pierre Doumenq ${ }^{\mathrm{e}}$, \\ Loke Ming Chou ${ }^{\mathrm{f}}$ \\ a Center for Maritime Biosciences Studies - Institute for Sciences and Community Service, Jenderal Soedirman University, Kampus Karangwangkal, Jl. Dr. Suparno, Purwokerto, \\ 53123, Indonesia \\ ${ }^{\mathrm{b}}$ Marine Science and Fisheries Faculty - Raja Ali Haji Maritime University, Jl. Politeknik Senggarang-Tanjung pinang, Riau Islands Province, 29100, Indonesia \\ ${ }^{\mathrm{c}}$ Marine and Fisheries Agency - Riau Islands Province Dompak, Bukit Bestari, Tanjung pinang, Riau Islands, Indonesia \\ ${ }^{\mathrm{d}}$ Fisheries and Marine Science Faculty - Jenderal Soedirman University, Kampus Karangwangkal, Jl. Dr. Suparno, Purwokerto, 53123, Indonesia \\ e Aix Marseille Université, CNRS, LCE, UMR 7376, 13545, Aix-en-Provence, Cedex 4, France \\ ${ }^{\mathrm{f}}$ Tropical Marine Science Institute, National University of Singapore, 5 Kent Ridge Road, Singapore, 119214, Republic of Singapore
}

* Corresponding author. Center for Maritime Biosciences Studies - Institute for Sciences and Community Service, Jenderal Soedirman University, Kampus Karangwangkal, Jl. Dr. Suparno, Purwokerto, 53123, Indonesia.

\begin{abstract}
A B S T R A C T
The impact of low-density polyethylene (LDPE) microplastics (<100 $\mu \mathrm{m}$; P100-A P100-B, P100-C, $100-200 \mu \mathrm{m}$; P200, 200-500 $\mu \mathrm{m}$; P500) on Acropora formosa was investigated. This study investigated the bleaching and necrosis extent of $A$. formosa caused by LDPE contamination via laboratory assay. The staghorn coral ingested the microplastics, resulting in bleaching and necrosis that concomitantly occurred with the release of zooxanthellae. P100-A experimentation was the worst case, showing bleaching by day $2(10.8 \pm 2.2 \%)$ and continued bleaching to $93.6 \% \pm 2.0$ by day 14 followed by $5.9 \pm 2.5 \%$ necrosis. The overall results confirmed that the LDPE concentration impacts coral health. We highlighted that microplastics have been ingested and partially egested. Their presence showed either a direct or indirect impact on coral polyps via direct interaction or through photosynthesis perturbation due to microplastics that cover the coral surface.
\end{abstract}

\section{Introduction}

Plastic production has increased by 650\% since 1975 and has reached 322 million metric tons in the year 2015 (Jambeck et al. 2015 ). In developing countries such as Indonesia, plastic wastes are not well managed and can enter the sea through land runoff, industrial activity and other sources as debris. The photolytic pro-cess, thermal-oxidation, weathering, hydrolytic removal and large biotics all contribute to accumulations and obvious fragmentations of plastic debris, thus resulting in the subsequent transformation of the debris into microplastics (Andrady, 2011). These microplastics have become a global issue and a growing environmental concern (GESAMP, 2015). In addition to macroplastics, the occurrences and impacts of microplastics were also studied in surface water (Barnes et al. 2009; Syakti et al. 2017), the water column (Lattin et al. 2004), sediments (Van Cauwenberghe et al. 2015) and even in a deep sea habitat (Fischer et al. 2015). In recent years, studying the adverse effects of microplastics on marine species to increase scientific knowledge on this subject has become an increasingly common endeavor. For instance, Wright et al. (2013) reviewed the physical and chemical impacts of microplastics that may be ingested by marine invertebrate from low trophic fauna and translocated the microplastics via the trophic transfer. The microplastics hazard has also been reported recently by Lusher et al. (2015). Others have studied the dangers of microplastics being ingested by various or-ganisms, including bivalves (Faggio et al., 2018), fish (Halstead et al., 2018) or even fish larvae (Steer et al. 2017), clams and worms (Van Cauwenberghe et al. 2015), crabs (Watts et al., 2014), and zooplankton (Cole et al. 2015; Sjollema et al., 2016). However, microplastics studies on scleractinian coral are still limited. Few studies cited here have included the interaction of microplastics with corals (Hall et al. 2015; Allen et al. 2017) and their physio-logical responses to chemoreception and subsequent declines in health (Allen et al. 2017; Reichert et al. 2017).

With 2,915,000 square kilometers of marine area, Indonesia encompasses by $17 \%$ of the world's total coral reef area, but $82 \%$ of it is at risk (Reefbase, 2018). To the best of our knowledge, this paper is the very first work dealing with the effects of microplastics on coral reefs. In this study, we hypothesized whether coral can ingest microplastics and low-density polyethylene (LDPE) and how it can affect coral health (bleaching and necrosis). To test this hypothesis, we used LDPE microplastics powder as the contaminant model in an aquarium system with Acropora formosa (Dana, 1846), a species that is widely distributed in Indonesian reef waters. LDPE is one of the most plastic usage in particularly for bottle caps, which are commonly found in marine environments (GESAMP, 2015). We tested the working hypothesis of whether A. formosa has the ingestion capacity for the LDPE microplastics powder and the po-tential effects of microplastics on, at least in part, the physical form of the coral or any potential leaching of unknown additives to the coral (Hall et al., 2015; Allen et al., 2017; Hankins et al., 2018). For this purpose, we investigated the immediate impacts of LDPE microplastics on A. formosa health after the exposure of coral to LDPE materials and their leachates.

\section{Methodology}

\subsection{Coral selection and sampling}

Acropora formosa (Dana, 1846) colony fragments were collected from waters of Bintan Island, in the Beralas Pasir island reef slope. The colonies were easily identified by a brown or cream color and the colonies are arborescent, with cylindrical branches. A. formosa is usually a dominant species that stands over $5 \mathrm{~m}$ across. Since divers collected $A$. formosa at $4-7 \mathrm{~m}$ of depth, the branches are 
often short and compact. They are distinct because they have exerting axial corallites and tubular radial corallites that vary in size and show regular colonization. Two to four branches of the 72 coral fragments that have $3-5 \mathrm{~cm}$ long terminal branches and a diameter of more than $1 \mathrm{~cm}$ were cut using zinc alloy hand pruning shears. The fragments were then transported to the laboratory using box containers filled with seawater that was taken from the depth where the corals were collected.

\subsection{Experimental design}

In the laboratory, coral fragments were attached by cable ties to a small ceramic sheet platform perforated by a screw as a holding pole in the center of the ceramic sheets $(12 \mathrm{~cm} \times 15 \mathrm{~cm})$. Fragments were then acclimated to the experimental system 10 days prior to the start of the experiment. Two series of 14 days experiments were performed after the acclimatization of $A$. formosa in aquaria con-taining $25 \mathrm{~L}$ of natural seawater $(60 \times 25 \times 20 \mathrm{~cm})$. The first series was conducted to test whether the coral has the capacity to ingest the microplastics, as well as any hazards they posed to A. formosa. In this series, 12 aquaria are used for trials associated with 3 sizes of microplastics $(<100 \mu \mathrm{m} ; 100-200 \mu \mathrm{m} ; 200-500 \mu \mathrm{m})$. Each size class treatment was performed in triplicate in three different aquaria, including a control. For each aquarium, 6 fragments of $A$. formosa were placed in aquaria prior to LDPE exposure. LDPE is prepared by gridding $19 \mathrm{~L}$ gallon caps via a commercial grinding machine and then sieving through different mesh sizes. A contamination was detected at a concentration of approximately $0.15 \mathrm{~g}$. $\mathrm{L}^{-1}$.

The second series is carried out in order to test whether the increasing concentration of microplastics influencing the impact. The second series used 12 aquaria, where 3 aquaria serve as con-trols and three others in the series serve as a treatment with different concentrations i.e., $0.05 \mathrm{~g}$. $\mathrm{L}^{-1}, 0.1 \mathrm{~g}$. $\mathrm{L}^{-1}$, and $0.15 \mathrm{~g}$. $\mathrm{L}^{-1}$ using $<100 \mu \mathrm{m}$ microplastics size. In this series, we also monitored the number of zooxanthellae during the time of experimentation. One fragment was harvested per aquarium with a $\mathrm{n}=3$ per treat-ment at each day of harvest. Coral fragments were harvested on day- 0 , day- 2 day- 4 day-7, ay-10 and day-14. Once harvested the fragments were rinse with sea water and can be stored at freezer prior for the analyse.

All aquaria were placed and kept at a temperature of $28.0^{\circ} \mathrm{C} \pm 1.0^{\circ} \mathrm{C}$ and a salinity of $32.0 \pm 0.5 \mathrm{ppt}$ in an acclimatized room. Room temperature was $27^{\circ} \mathrm{C}$ and was equipped with sub-mersible heaters commercial in the aquaria with a set temperature of $28.0{ }^{\circ} \mathrm{C}$ to offset any temperature descent in the evening. The aquaria was static of flow through and undergo we added regular water refill into system each two day which is losse due to exper-imentation and evaporation. To enhance zooxanthellae production, a light-dark cycle was set up as 24:0. Other water quality param-eters such as $\mathrm{pH}$, temperature and dissolved oxygen were measured daily using a Lutron Elektronic for pH/ORP, DO, CD/TDS meter type YK-2005WA.

\subsection{Visual observation}

Samples were observed using Nikon Binoculars and Binoculars Optima Microscopes with 100-400 times magnification. Plankton abundance was observed using a Sedgewick Rafter Counting Chamber (SRC) (APHA, 2012). A rapid identification of zooxan-thellae was performed using the World Registration of Marine Species website (www.marinespecies.org).

\subsection{Microplastic identification}

LDPE microplastics are prepared by gridding 19 L gallon caps via a commercial grinding machine and then sieving through different range of mesh size used. The microplastic polymers were confirmed using Fourier transform infrared (FTIR) spectroscopy. Powder samples and fragments of plastic cups were compressed in a diamond crystal Smart Orbit ${ }^{\mathrm{TM}}$ accessory, and the infrared spectra were obtained using a Thermo Electron Nexus spectrometer (Syakti et al. 2017). The spectra were recorded as an attenuated total reflection (ATR) and were corrected using the ATR correction in OMNIC ${ }^{\text {тм }}$ software. All the spectra were acquired between 4000 and $450 \mathrm{~cm}^{-1}$, with 64 accumulations and a spectral resolution of $4 \mathrm{~cm}^{-1}$. The spectra will be corrected for removing $\mathrm{H}_{2} \mathrm{O}$ and $\mathrm{CO}_{2}$ absorption ca. $2300-2400 \mathrm{~cm}^{-1}$. The polymer identification was performed based on vibrational bands and a comparison of IR spectra against standards in a spectral library with $>85 \%$ similarity, with the polymer matching references.

\subsection{Determination of surface area on impacted polyp colonies}

Coral surface areas were determined as an average by four in-dividual observers' (students) estimated calculations of the frag-ment surface by a modified aluminum foil wrapping methods (Bergey and Getty, 2006; Veal et al. 2010). Briefly, a linear regres-sion curve was fitted from the surface area data of the cut aluminum foil $\left(1,2,3,5,7.5,10,15,20,25\right.$ and $\left.50 \mathrm{~cm}^{2}\right)$ and its weights. Moreover, each coral fragments was then carefully wrapped in the foil by minimizing the overlapping of the foil. The weight of aluminum foil used to cover each coral fragments was then used to estimate the surface area. The provided data show the percentages of the good, necrosis and bleaching surface areas that cover the fragments.

\subsection{Dissolving and extracting the coral living tissues and nonliving skeleton}

To estimate the amount of the LDPE powder ingested in the A. formosa polyp colonies, a frozen coral sample was dissolved in a minimum volume of formic acid for 60 min to dissolve both its tissue and skeleton. The free plastics were found in the supernatant liquid and then were transferred to a glass beaker prior to evapo-ration. The remaining residues, including plastic, were oxidized using $\mathrm{H}_{2} \mathrm{O}_{2} 4 \%$ to eliminate the organic materials absorbed into plastic particles. Plastics were then separated from remaining substances in a $\mathrm{ZnCl}_{2}(5 \mathrm{M})$ solution. The floating plastics were separated by filtration and weighted. 


\subsection{Statistical analysis}

All observations are presented as the mean values \pm their stan-dard deviations (SDs). All statistical data analyses were performed using Microsoft Excel. Variations within the stations were assessed based on an ANOVA test. Values are reported as the mean \pm SD, and the differences are considered significant when $\mathrm{p}<0.05$.

\section{Results and discussion}

\subsection{Acropora formosa}

We estimated the average of the A. formosa polyps and mouth sizes from the fragments stored in 12 aquaria by randomly taking 5 measurements of the selected fragments $(\mathrm{n}=60)$. The results show that the polyp sizes ranged from $2.75 \mathrm{~mm}-3.23 \mathrm{~mm}$ with arithmetical means of $2.98 \pm 0.87 \mathrm{~mm}$. Furthermore, we estimated the mouth sizes from 12 selected aquarium fragments from which 5 measurements were randomly conducted to estimate the A. formosa mouth size. Our results showed that the average mouth size was approximately $1750 \pm 246 \mathrm{~mm}\left(\mathrm{n}^{1 / 4} 60\right)$ (ranged from $350 \mathrm{mme} 2015 \mathrm{~mm}$ ). This result supports our experimental design of using three microplastic sizes i.e., $<100 \mathrm{~mm}, 100 \mathrm{e} 200 \mathrm{~mm}$, and $200 \mathrm{e} 500 \mathrm{~mm}$.

During the experiment, $\mathrm{pH}, \mathrm{DO}$, and temperature were observed. The patterns of seawater $\mathrm{pH}$ and DO are shown in Fig. 1 . During the first 7 days, the $\mathrm{pH}$ ranged from $7.31 \pm 0.34$ to $7.93 \pm 0.08$. In this treatment, seawater pH gradually decreased to $6.73 \pm 0.28$ (see Fig. 1 ). Due to evaporation, the aquariua were supplied by fresh sea water at an extent of 5-10\% of the total vol-ume of seawater; this replacement led to the $\mathrm{pH}$ being increased to approximately $8.2 \pm 0.23$. Afterward, from day 8 to day 14 , there was a continuous decrease in the pH that reached $6.30 \pm 0.09$. Regarding the $\mathrm{pH}$ pattern, the experiment showed that measure-ments in the morning (06:00-08:00) had a lower $\mathrm{pH}$ compared to the evening samplings, which were not significantly different from each other $(\mathrm{P}>0.05)$. The mean of the $\mathrm{pH}$ in the morning $(7.2 \pm 0.65)$ was lower than that in the evening $(7.39 \pm 0.61)$. The ranges of $\mathrm{pH}$ in this experiment had similar or greater magnitudes as those of previous studies (Cervino et al. 2003; Enochs et al. 2018) and were similar to those observed in the field (Chan and Eggins, 2017). DO ranged from $6.49 \pm 0.98$ to $7.12 \pm 0.46$ and showed a significant decrease at the end of the experiment (days 13 and 14 ), which fell to $4.56 \pm$ 0.58 and $4.78 \pm 0.45$, respectively. This phe-nomenon may be directly related to biological decay due to coral necrosis and bleaching. Temperatures were stable at $28.13 \pm 0.57{ }^{\circ} \mathrm{C}$ to $28.64 \pm 0.53{ }^{\circ} \mathrm{C}$, while from day 7 to day 14 , there was a slight decrease in temperature $\left(27.58 \pm 0.07^{\circ} \mathrm{C}\right.$ to $\left.27.73 \pm 0.09{ }^{\circ} \mathrm{C}\right)$.

\subsection{LDPE confirmation}

The verification of the microplastics polymer used in this study was done via FTIR ATR spectroscopy. Fig. 2 shows the LDPE poly-mers that were indicated by the prominent presence of the $2911 \mathrm{~cm}^{-1}, 2847 \mathrm{~cm}^{-1}$, and $1467 \mathrm{~cm}^{-1}$ absorbing groups and their match degrees compared to the standard spectra. The bands at 2911 and $2847 \mathrm{~cm}^{-1}$ corresponded to $\mathrm{C}-\mathrm{H}$ stretching, indicating asym-metrical vibrations, symmetrical stretching $\left(\mathrm{v}_{\mathrm{a}}-\mathrm{CH}_{3}\right)$, and $\mathrm{v}_{\mathrm{a}}\left(\mathrm{CH}_{3}\right)$, while the band $1467 \mathrm{~cm}^{-1}$ spectral assignment represented asym-metrical deformation vibrations $\left(\delta-\mathrm{CH}_{2}\right)$. LDPE was characterized by high $\mathrm{CH} 3$ methyl groups as shown by an intense $720 \mathrm{~cm}^{-1}$ peak, with its assignments indicating an asymmetrical methyl $\mathrm{C}-\mathrm{H}$ bending or methylene scissoring; these indications reflect the methylene rocking in the $\mathrm{C}$ - $\mathrm{H}$ out-ofplane bending region $\left(\gamma_{\mathrm{r}}-\mathrm{CH}_{2}\right)$.

\subsection{Impact of LDPE microplastics on A. formosa health (bleaching and necrosis)}

During the course of the experiment, results showing no bleaching was observed in the control. We report in Figs. $3-5$ that plastics of larger sizes had fewer impacts on coral health. The P500 and P200 treatments showed no significant differences in coral health percentages until the 7th day. Starting from the 10th day, coral bleaching was observed and caused major health losses to the colonies. For instance, the P500 results in unhealthy colonies showed coral bleaching extent from $9.8 \pm 2.7 \%$ to $25.2 \pm 7 \%$ at the end of experiment (14 days), with the bleaching accompanied by a slight necrosis symptom quantified at $1.3 \pm 0.5 \%$ (10th day) and $1.6 \pm 3.4 \%$ (14th day). Hankins et al. (2018) recently demonstrated the ingestion and egestion of 425-500 $\mu \mathrm{m}$ microplastics on Mon-tastrea cavernosa and Orbicella faveolata. The worst case was found 

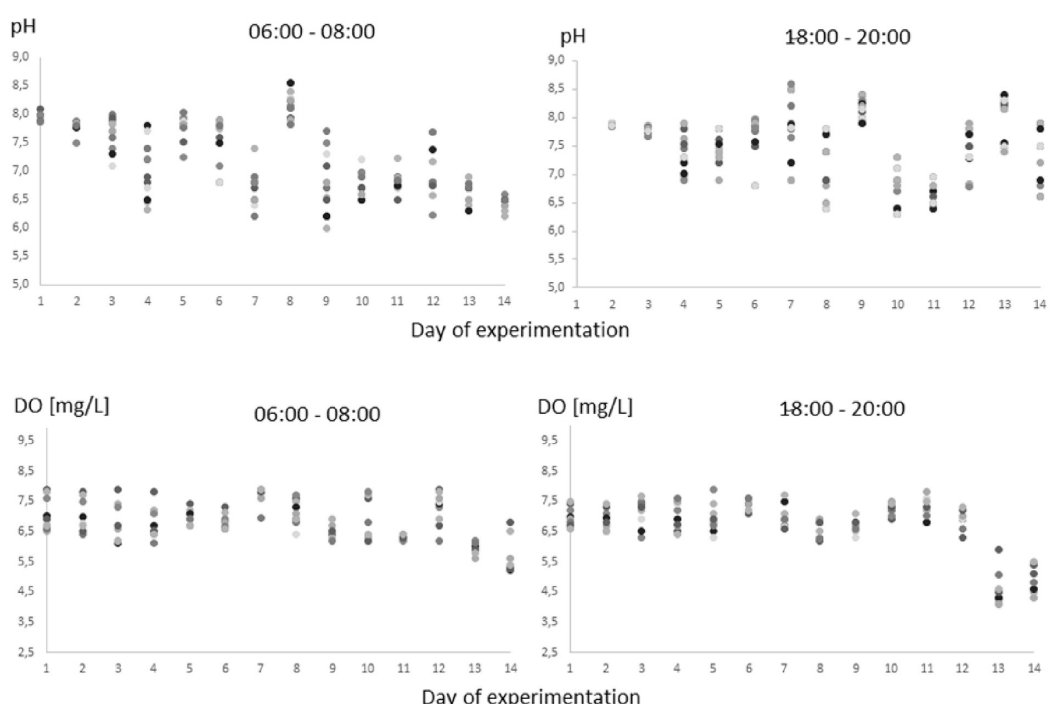

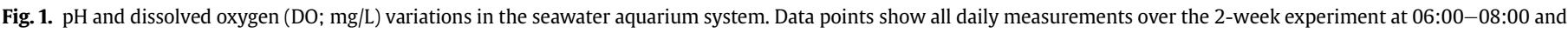
18:00-20:00

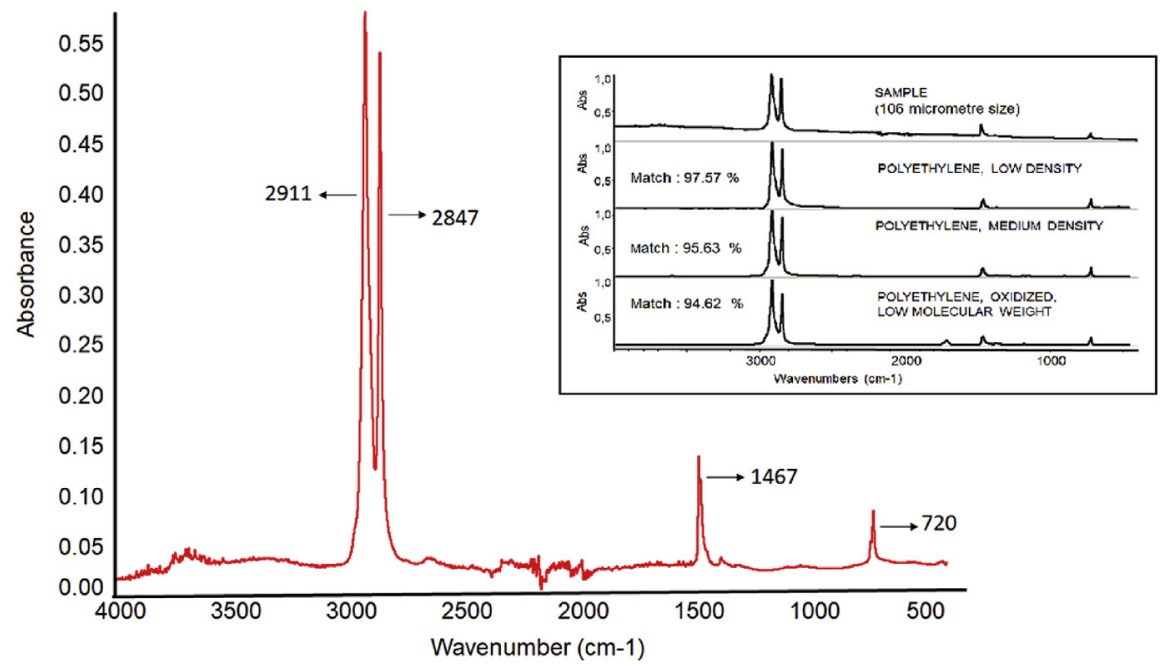

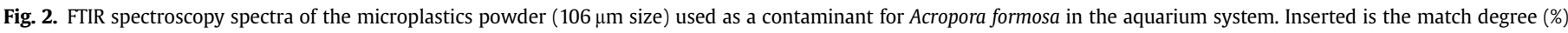
with the standard spectra. Characteristic bands are shown by arrows.

in the P100-A experimentation, where LDPE microplastics with a $100 \mu \mathrm{m}$ size were used with a concentration of $0.15 \mathrm{~g} / \mathrm{L}$. Bleaching was directly observed by day $2(10.8 \pm 2.2 \%)$ and continued in day $4(24.1 \pm 6.8 \%)$, with the first appearance of necrosis polyps by an extent of $0.4 \pm 0.6 \%$ in the latter. By days 7 and 10 the bleaching dramatically increased to $55.7 \pm 5.8 \%$ and $83.5 \pm 1.8 \%$, respectively, followed by necrosis expansions of $2.3 \pm 0.7 \%$ and $5.7 \pm 1.9 \%$ respectively. At the end of the experiment, the full bleaching extent was $93.6 \% \pm 2.0$, followed by $5.9 \pm 2.5 \%$ necrosis (see Fig. 6). The observed results suggested that the size of the microplastics had a direct impact on coral health. A significant difference was observed among the treatments at $\mathrm{p}<0.005$ when comparing the P100-A, P200, and P500 experiments. To answer whether the concentra-tions of the microplastics will also impact the health of the coral, we conducted two other series of experiments, P100-B (0.1 g/L) and P100-C (0.05 g/L), by using a microplastics size of less than $100 \mathrm{~mm}$ (Fig. 3).

The results showed that starting from day 2 , bleachings were recorded at $1.7 \pm 0.2 \%(\mathrm{P} 100-\mathrm{B})$ and $3.1 \pm 1.0 \%(\mathrm{P} 100-\mathrm{C})$. On day 4 , the corals continued to bleach at $8.2 \pm 0.8 \%(\mathrm{P} 100-\mathrm{B})$ and $8.9 \pm 1.3 \%(\mathrm{P} 100-\mathrm{C})$ while necrosis was recorded at $0.7 \pm 1.0 \%(\mathrm{P} 100-\mathrm{B})$ and $4.6 \pm$ $1.2 \%(\mathrm{P} 100-\mathrm{C})$.

Moreover, the bleaching continued to expand on day 7, day 10 and day 14 , which showed values of $37.7 \pm 8.1 \%, 60.8 \pm 17.4 \%$ and $77.7 \pm 1.6 \%$, respectively, for P100-B. Concomitantly, we noted the necrosis coverages were $2.2 \pm 2.9 \% 3.0 \pm 2.2 \%$ and 4.2 $\pm 1.9 \%$, respectively. When the concentration of LDPE was applied at $0.05 \mathrm{~g} / \mathrm{L}$, its impact was less important compared to P100$\mathrm{A}$ and P100-B but showed a similar pattern in bleaching coverage as $19.5 \pm 2.8 \%, 38.6 \pm 7.2 \%$ and $62.5 \pm 7.6 \%$, respectively. However, the necrosis observation extents were higher compared to other treatments, showing $8.0 \pm 1.1 \%, 9.9 \pm 0.3 \%$ and 7.6 $\pm 0.6 \%$, respectively, for days 7,10 and 14 .

The impacts microplastics have on corals have been previously observed by Reichert et al. (2017), who showed a cleansing mech-anism by producing mucus and showed a feeding interaction with mesentrial filament and egestion, including bleaching and tissue necrosis. Our study showed similar impacts to those observed by Reichert et al. (2017) and Hankins et al. (2018). 


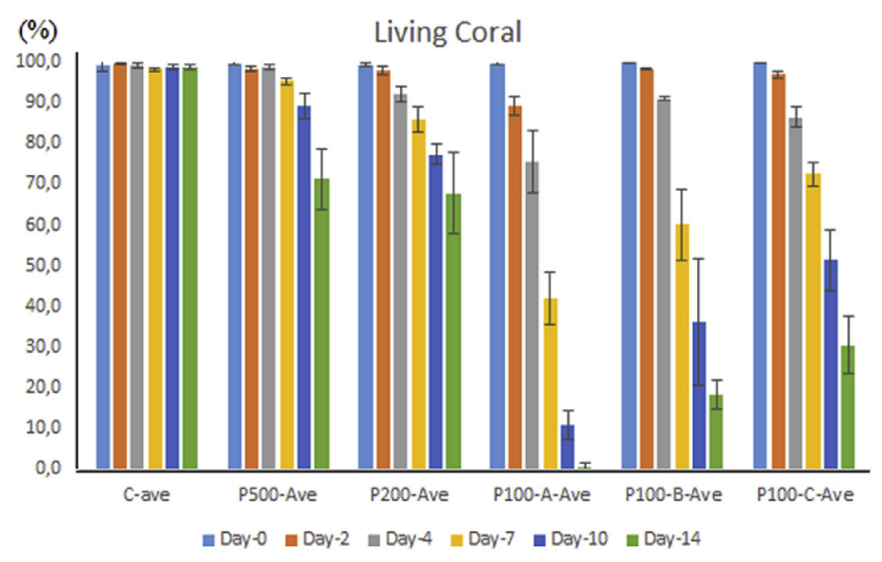

Fig. 3. The living coral surface area using different experimental treatments over 14 days. The averages and standard deviations were obtained in triplicate.

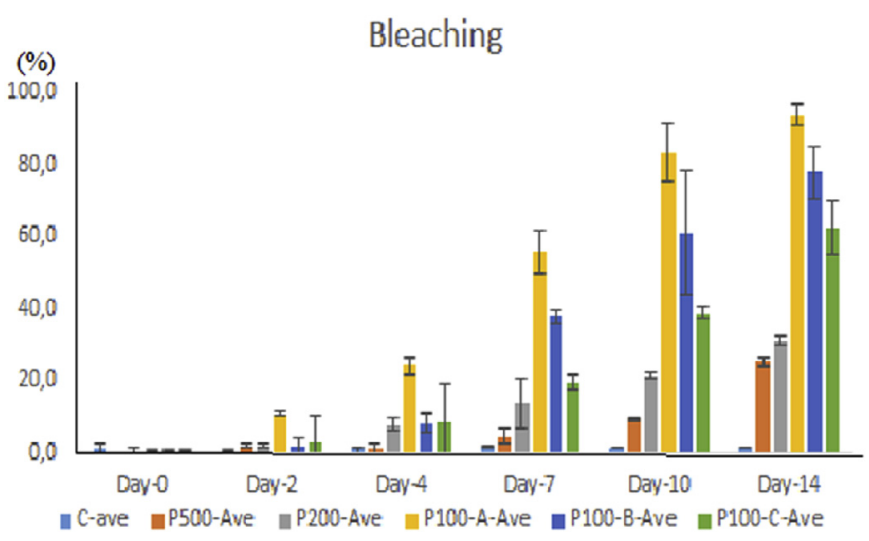

Fig. 4. The bleaching surface percentage coverage using different experimental treatments over 14 days. The averages and standard deviations were obtained in triplicate.

\section{Necrosis}

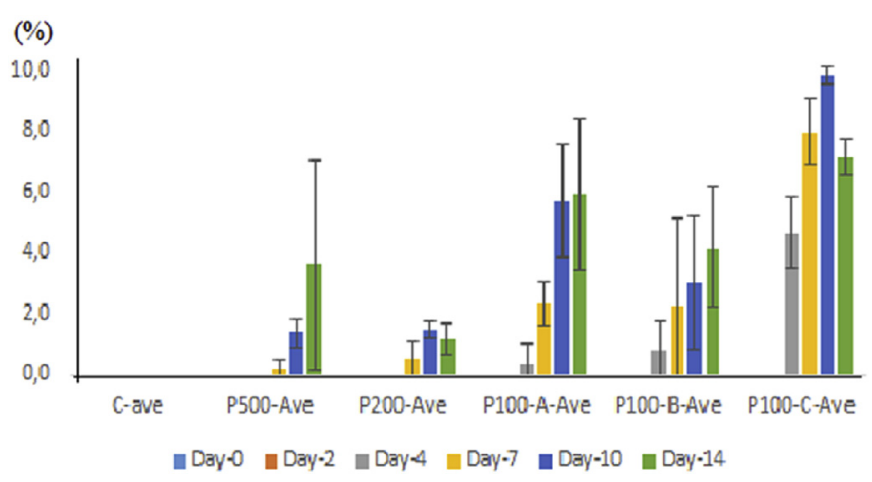

Fig. 5. The necrosis surface percentage coverage using different experimental treatments over 14 days. The average and standard deviation were obtained in triplicate.

Consequently, the impacts of microplastics on A. formosa may be hypothesized from two perspectives: (i). microplastics covering the surface of $A$. formosa reduce light penetration necessary for endo-symbiont zooxanthellae photosynthesis (Fig. 7). Most authors confirmed the influence of light intensity on zoothantellae (Mortillaro et al. 2009; Kuguru et al. 2010), but none stated that reduction in light intensity was caused by placing covering mate-rials onto coral tissues. Most articles observing zooxanthellae released by the intact corals were caused by an increase in tem-perature and nutrient loading (Stimson and Kinzie, 1991; Tanaka et al. 2014). (ii). The toxicity of the chemicals associated with LDPE to corals that were related to the ingredients of the plastic materials and possibly leached some possibly hazardous sub-stances such as colorants and flame retardants. Even though LDPEs are less toxic compared to other plastic type polymers, there is still a risk for the leaching of additives and oligomers, including for example, BPA, phthalates, citrates, and styrene oligomers (Hansen et al. 2013; Hahladakis et al. 2018). We expected that if the toxic chemicals had any direct or indirect influences on coral, they would negatively impact the zooxanthellae. We are aware that if zooxanthellae leave the coral, a bleaching event will obviously be observed. To test this sub-hypothesis (direct/indirect toxic effect on coral), we calculated and compared the amount of ingested microplastics and the number of zooxanthellae during the 14-day experimental period between control and P100-A (Tables 1 and 2).

\subsubsection{Ingested microplastics}

Since P100-A showed a remarkable impact of microplastics, we extracted the three-four fragments of $A$. formosa representing the P100A treatment for day 0 , day 2, day 4, day 7, day 10 and day 14. Table 1 shows that after 6 h, we could already detect the LDPE microplastics trapped in the mesentrial of the coral polyps at an extent of $9 \pm 7.5 \mathrm{mg}$. The amount slightly increased on day 2 at a significantly different extent than that of day 0 (P. 0.05). The ex-tracts of corals on day 7 showed an important microplastics ingestion action at an extent of $1.02 \pm$ $0.19 \mathrm{mg}$ and reached the maximum at day 7 with an extent of $477 \pm 64.7 \mathrm{mg}$. However, the LDPE mesentrial trapping extent decreased to $348.7 \pm 32.5 \mathrm{mg}$ and $236.8 \pm 46.3 \mathrm{mg}$ on day 10 and day 14 , respectively. Reichert et al.(2017) also showed the ingestion of $37-163 \mu \mathrm{m}$ of microplastics by the genera of Acropora, Pocillopora and Porites.

\subsubsection{Egested microplastics}

To estimate whether coral egest the microplastics, we also counted the microbeads formed by microplastics during the experiment. Microbeads is an accumulation of the microplastics deposited on the surface of the ceramics sheets. At day- 0 , the microplastic beads (microbeads) had already formed at an extent of $0.16 \pm 0.2 \mathrm{mg} / \mathrm{cm} 2$ and continued to precipitate at $0.19 \pm 0.05 \mathrm{mg} / \mathrm{cm} 2 \mathrm{on}$ day 2 . We suggest that this value was not correspondent to a settling of microplastics due to the enhancement of a density bulk biofouling that led to an increase in density and facilitated sedimentation. It is possible that the microbeads were present as a result of the adherents of microplastics bonding to the bead surface, not egestion. The microbead formation extent increased to $1.02 \pm 0.19 \mathrm{mg} / \mathrm{cm} 2$ and $1.27 \pm 0.32 \mathrm{mg} / \mathrm{cm} 2$ on day 4 and day 7 , respectively. Interestingly, by this time (day 7 ), the ingestion was reported at its maximum but the microbead formation extent increased progressively until the end of the experiment. This result suggests the egestion might have occurred at a greater magnitude after day 7 . 


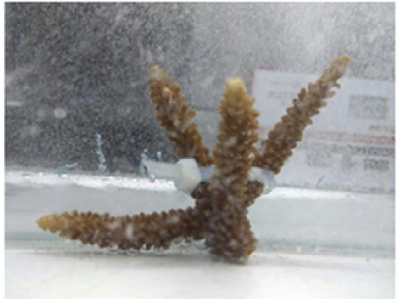

(A)

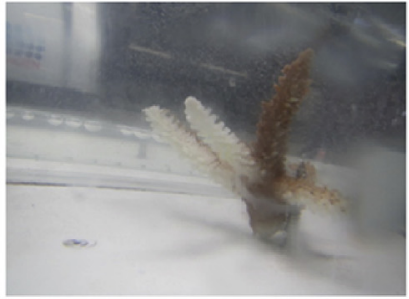

(B)

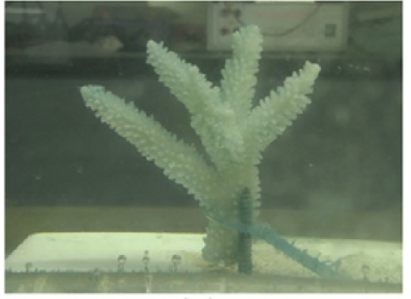

(C)

Fig. 6. Microplastic impacts during 14 days of experimentation. A (day 2), B (day 7), and C (day 14).

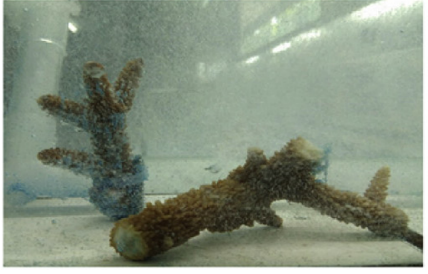

(A)

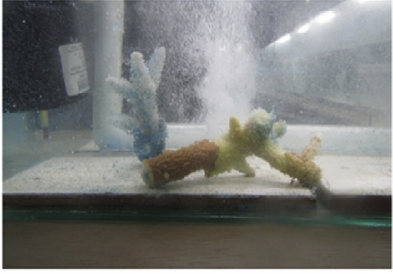

(B)

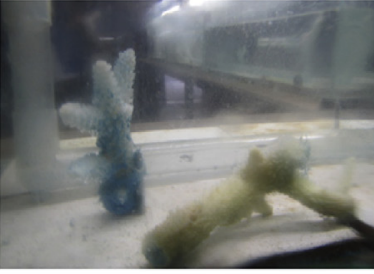

(C)

Fig. 7. Microplastic covering the A. formosa polyps at 14 days of experimentation. A (day 2), B (day 7), and C (day 14).

Table 1

Ingested microplastics (mg) by Acropora formosa over 14 days and microbeads deposition $\left(\mathrm{mg} / \mathrm{cm}^{2}\right)$.

\begin{tabular}{|c|c|c|c|c|c|c|}
\hline Assays & Day 0 & Day 2 & Day 4 & Day 7 & Day 10 & Day 14 \\
\hline P100-A & $9 \pm 7.5$ & $54.2 \pm 16.6$ & $119 \pm 36.4$ & $477 \pm 647$ & $348.7 \pm 32.5$ & $236.8 \pm 46.3$ \\
\hline Microbead deposition & $0.16 \pm 0.2$ & $0.29 \pm 0.05$ & $1.02 \pm 0.19$ & $1.27 \pm 0.32$ & $2.23 \pm 1.32$ & $4.13 \pm 0.89$ \\
\hline
\end{tabular}

Table 2

Zooxanthellae abundance (cells/L) in aquarium water over 14 days. $\mathrm{nd}=$ not detected.

\begin{tabular}{|c|c|c|c|c|c|c|}
\hline & Day 0 & Day 2 & Day 4 & Day 7 & Day 10 & Day 14 \\
\hline Control & nd & nd & $187 \pm 160$ & $93 \pm 162$ & $280 \pm 280$ & $467 \pm 162$ \\
\hline P100-A & $280 \pm 196$ & $560 \pm 485$ & $5133+3556$ & $6533 \pm 647$ & $19,693+4277$ & $36,773 \pm 6580$ \\
\hline
\end{tabular}

As previously reported, some species are capable to egest, retain or immobilize the microplastics into their organ cir-culation (Setälä et al. 2014; Imhof et al. 2017; Lehtiniemi et al. 2018). Regarding our results, the ingestion of $A$. formosa was of a similar or greater magnitude than what was found by Allen et al.(2017), who observed that coral retained $8 \%$ of the ingested plas-tics. Briefly, predicting the ingestion versus egestion occurrence extent is a complex phenomenon that involves many processes and determining a certain pattern.

\subsubsection{Zooxanthellae releases}

We observed two distinct zooxanthellae species, i.e. Symbio-dium sp and Gymnodinium sp. Those species have been referred to as freeliving symbiotic dinoflagellate genera (Gou et al., 2003; Santos, 2004). Our finding shows that the microplastics remarkably and significantly influenced the releases of zooxanthellae in the water column. An immediate effect was observed on the first day after $3-6$ h of microplastics contamination by observing $280 \pm 196$ cells/l. It is possible that this response corresponded to the time of $A$. formosa ingesting the microplastics, thus resulting in a stress response in the internal mechanism of the coral system. We do not yet understand such a mechanism, but we suggest it will disturb the intact zoothantellae and then force them out of the coral tissues. Our results also did not support the natural phe-nomena controlling the postmitotic phase that regulates the den-sity within coral tissues (Littman et al. 2008). The number of zooxanthellae increased over time and gave a maximum value at the end of experimentation of 36,773 \pm 6580 cells/l. We noted that some dead cells or debris of zooxanthellae might not have been calculated. In the control, we also observed the release of zooxanthellae from day 4 to day 14, but there was no significant difference during the course of the experiment. Our results were lower than those of Littman et al. (2008), who observed zooxanthellae abundances in their natural habitat; their results ranged from 1-4 x 106 cells/L. Additionally, as observed by Shaw et al. (2012), some pollutants, i.e., herbicides, may influence the photosynthetic po-tential of zooxanthellae and impact the coral via the bleaching symptom. 


\section{Conclusion}

In the present study, we suggest that microplastics suppress the health of $A$. formosa corals when applying the smallest sizes of LDPE particles. We also showed their immediate impacts in the form of coral necrosis and/or bleaching caused by increasing concentrations of LDPE exposure. The increased number of zooxanthellae in the water column confirmed that the bleaching occurred after zooxanthellae leave the coral polyps due to LDPE artificial contamination. We suggest that microplastics, in general, disturb coral polyps either through direct or indirect interaction or through photosynthesis perturbation due to the microplastics covering the surface of the coral. Future studies will need to focus on the leaching of plastic adjuvants that may prove potentially toxic. Another emerging issue is to understand the observed necrosis that may be related to the postmitotic mechanism or pathogens.

\section{Acknowledgements}

The authors are thankful for the financial support of DemandDriven Research Grant (DDRG) from Coral Reef Rehabilitation and Management Project-Coral Triangle Initiative (COREMAP-CTI) From P2O-LIPI No: B-1968/IPK.02/KS/III/2018. Dr. Syakti's special thanks are dedicated to his students who participated during this study (Suteri, Dea, Anggie, Liya, Tital, Reni, and Iqbal) from the Marine Science and Aquatic Resources Department, Raja Ali Haji Maritime University.

\section{Appendix A. Supplementary data}

Supplementary data to this article can be found online at https://doi.org/10.1016/j.chemosphere.2019.04.156.

\section{References}

Allen, A.S., Seymour, A.C., Rittschof, D., 2017. Chemoreception drives plastic consumption in a hard coral. Mar. Pollut. Bull. 124, 198-205.

Andrady, A.L., 2011. Microplastics in the marine environment. Mar. Pollut. Bull. 62, 1596-1605.

APHA, 2012. In: E.W, Rice, R.B., Baird, A.D., Eaton, L.S. (Eds.), Standard Methods for the Examination of Water and Wastewater, twenty-second ed. Clesceri. American Public Health Association, Virginia.

Barnes, D.K.A., Galgani, F., Thompson, R.C., Barlaz, M., 2009. Accumulation and fragmentation of plastic debris in global environments. Philos. Trans. R. Soc. B: Biol. Sci. 364, 1985-1998.

Bergey, E.A., Getty, G.M., 2006. A review of methods for measuring the surface area of stream substrates. Hydrobiologia 556, 7-16.

Cervino, J.M., Hayes, R.L., Honovich, M., Goreau, T.J., Jones, S., Rubec, P.J., 2003. Changes in zooxanthellae density, morphology, and mitotic index in hermatypic corals and anemones exposed to cyanide. Mar. Pollut. Bull. 46, 573-586.

Chan, W.Y., Eggins, S.M., 2017. Calcification responses to diurnal variation in seawater carbonate chemistry by the coral Acropora formosa. Coral Reefs 36, $763-772$.

Cole, M., Lindeque, P., Fileman, E., Halsband, C., Galloway, T.S., 2015. The impact of polystyrene microplastics on feeding, function and fecundity in the marine copepod Calanus helgolandicus. Environ. Sci. Technol. 49, 1130-1137.

Dana, J.D., 1846. United States Exploring Expedition during the years 1838-1842. Zoophytes, 7. Lea and Blanchard, Philadelphia, pp. 1-740.

Enochs, I.C., Manzello, D.P., Jones, P.J., Aguilar, C., Cohen, K., Valentino, L., Schopmeyer, S., Kolodziej, G., Jankulak, M., Lirman, D., 2018. The influence of diel carbonate chemistry fluctuations on the calcification rate of Acropora cervicornis under present day and future acidification conditions. J. Exp. Mar. Biol. Ecol. 506, 135-143.

Faggio, C., Tsarpali, V., Dailianis, S., 2018. Mussel digestive gland as a model tissue for assessing xenobiotics: an overview. Sci. Total Environ. 636, 220-229.

Fischer, V., Elsner, N.O., Brenke, N., Schwabe, E., Brandt, A., 2015. Plastic pollution of the kuril-kamchatka trench area (NW pacific). Deep Sea Res. Part 2 Top. Stud. Oceanogr. 111, 399-405.

GESAMP, 2015. Sources, fate and effects of microplastics in the marine environment: a global assessment. Rep. Stud. GESAMP 90, 96.

Gou, W., Sun, J., Li, X., Zhen, Y., Xin, Z., Yu, Z., Li, R., 2003. Phylogenetic analysis of a free-living strain of Symbiodinium isolated from Jiaozhou Bay, P.R. China. J. Exp. Mar. Biol. Ecol. 296, 135-144.

Hahladakis, J.N., Velis, C.A., Weber, R., Iacovidou, E., Purnell, P., 2018. An overview of chemical additives present in plastics: migration, release, fate and environmental impact during their use, disposal and recycling. J. Hazard Mater. 344, 179-199.

Hall, N.M., Berry, K.L.E., Rintoul, L., Hoogenboom, M.O., 2015. Microplastic ingestion by scleractinian corals. Mar. Biol. 162, 725-732.

Halstead, J.E., Smith, J.A., Carter, E.A., Lay, P.A., Johnston, E.L., 2018. Assessment tools for microplastics and natural fibres ingested by fish in an urbanised estuary. Environ. Pollut. 234, 552-561.

Hankins, C., Duffy, A., Drisco, K., 2018. Scleractinian coral microplastic ingestion: potential calcification effects, size limits, and retention. Mar. Pollut. Bull. 135, 587-593.

Hansen, E., Nilsson, N.H., Lithner, D., Lassen, C., 2013. Hazardous Substances in Plastic Materials. http://www.miljodirektoratet.no/no/Publikasjoner/ Publikasjoner/2013/Februar/Hazardous_substances_in_plastic_materials/. (Accessed February 2018).

Imhof, H.K., Sigl, R., Brauer, E., Feyl, S., Giesemann, P., Klink, S., Leupolz, K., Loder, M.G.J., Loschel, L.A., Missun, J., Muszynski, S., Ramsperger, A.F.R.M., Schrank, I., Speck, S., Steibl, S., Trotter, B., Winter, I., Laforsch, C., 2017. Spatial and temporal variation of macro-, meso- and microplastic abundance on a remote coral island of the Maldives. Indian Ocean. Mar. Pollut. Bull. 116, $340-347$.

Jambeck, J.R., Geyer, R., Wilcox, C., Siegler, T.R., Perryman, M., Andrady, A., Narayan, R., Law, K.L., 2015. Plastic waste inputs from land into the ocean. Science 347, 768-771.

Kuguru, B., Achituv, Y., Gruber, D.F., Tchernov, D., 2010. Photoacclimation mechanisms of corallimorpharians on coral reefs: photosynthetic parameters of zooxanthellae and host cellular responses to variation in irradiance. J. Exp. Mar. Biol. Ecol. 394, 53-62.

Lattin, G.L., Moore, C.J., Zellers, A.F., Moore, S.L., Weisberg, S.B., 2004. A comparison of neustonic plastic and zooplankton at different depths near the southern California shore. Mar. Pollut. Bull. 49, 291-294.

Lehtiniemi, M., Hartikainen, S., Näkki, P., Engstrom-Ost, J., Koistinen, A., Setala, O., 2018. Size matters more than shape: ingestion of primary and secondary microplastics by small predators. Food Webs e00097.

Littman, R.A., Van Oppen, M.J.H., Willis, B.L., 2008. Methods for sampling free-living symbiodinium (zooxanthellae) and their distribution and abundance at lizard island (great barrier reef). J. Exp. Mar. Biol. Ecol. 364, 48-53.

Lusher, A.L., Hernandez-Milian, G., O'Brien, J., Berrow, S., O'Connor, I., Offcer, R., 2015. Microplastic and macroplastic ingestion by a deep diving, oceanic cetacean: the True's beaked whale. Mesoplodon mirus. Environ. Pollut. 199, 185-191.

Mortillaro, J.M., Pitt, K.A., Lee, S.Y., Meziane, T., 2009. Light intensity influences the production and translocation of fatty acids by zooxanthellae in the jellyfish Cassiopea sp. J. Exp. Mar. Biol. Ecol. 378, 22-30.

Reichert, J., Schellenberg, J., Schubert, P., Wilke, T., 2017. Responses of reef building corals to microplastic exposure. Environ. Pollut. 237, 955-960.

Santos, S.R., 2004. Phylogenetic analysis of a free-living strain of Symbiodinium isolated from Jiaozhou Bay, P.R. China. J. Phycol. 40, 395-397.

Setälä, O., Fleming-Lehtinen, V., Lehtiniemi, M., 2014. Ingestion and transfer of microplastics in the planktonic food web. Environ. Pollut. 185, 77-83.

Shaw, C.M., Brodie, J., Mueller, J.F., 2012. Phytotoxicity induced in isolated zooxanthellae by herbicides extracted from Great Barrier Reef flood waters. Mar. Pollut. Bull. 65, 355-362.

Sjollema, S.B., Redondo-Hasselerharm, P., Leslie, H.A., Kraak, M.H.S., Vethaak, A.D., 2016. Do plastic particles affect microalgal photosynthesis and growth? Aquat. Toxicol. 170, 259-261.

Steer, M., Cole, M., Thompson, R.C., Lindeque, P.K., 2017. Microplastic ingestion in fish larvae in the western english channel. Environ. Pollut. 226, 250-259.

Stimson, J., Kinzie, R.A., 1991. The temporal pattern and rate of release of zooxanthellae from the reef coral Pocillopora damicornis (Linnaeus) under nitrogenenrichment and control conditions. J. Exp. Mar. Biol. Ecol. 153, 63-74.

Syakti, A.D., Bouhroum, R., Hidayati, N.V., Koenawan, C.J., Boulkamh, A., Sulistyo, I., Lebarillier, S., Akhlus, S., Doumenq, P., Wong-Wah-Chung, P., 2017. Beach macrolitter monitoring and floating microplastic in a coastal area of Indonesia. Mar. Pollut. Bull. 122, 217-225.

Tanaka, Y., Inoue, M., Nakamura, T., Suzuki, A., Sakai, K., 2014. Loss of zooxanthellae in a coral under high seawater temperature and nutrient enrichment. J. Exp. Mar. Biol. Ecol. 457, 220-225.

Van Cauwenberghe, L., Devriese, L., Galgani, F., Robbens, J., Janssen, C.R., 2015. Microplastics in sediments: a review of techniques, occurrence and effects. Mar. Environ. Res. 111, 5-17.

Veal, C.J., Holmes, G., Nunez, M., Hoegh-Guldberg, O., Osborn, J., 2010. A comparative study of methods for surface area and three-dimensional shape measurement of coral skeletons. Limnol Oceanogr. Methods 8, 241-253.

Watts, A.J.R., Lewis, C., Goodhead, R.M., Beckett, S.J., Moger, J., Tyler, C.R., Galloway, T.S., 2014. Uptake and retention of microplastics by the shore crab Carcinus maenas. Environ. Sci. Technol. 48, 8823-8830.

Wright, S.L., Thompson, R.C., Galloway, T.S., 2013. The physical impacts of microplastics on marine organisms: a review. Environ. Pollut. 178, 483-492. 